\title{
Discussion: Potential structural deficiencies within the Gokteik Viaduct Railway Bridge in Upper Burma
}

David C. Wohlers PE, PMP

Professional Engineer, Bridge Inspection Team Leader, Independent

Researcher, Yreka, CA, USA (Orcid:0000-0003-2946-2332)

(dcwohlers@gmail.com

\section{Contribution by D. C. Wohlers}

The author of the original article (Wohlers, 2022) went to great lengths to search for original engineering drawings of the Gokteik Viaduct in Upper Burma. This search included the British Library, various museums, a steel company that now occupies the former site of the Pennsylvania Steel Company in Steelton, PA, USA, and numerous online archives. However, the exhaustive search yielded only one primary source that contained several details of the structure. The 26 January 1901 edition of Engineering Record showed a schematic cross-section of bent \#23 (Figure 5), a profile view of the entire bridge span with key spacing and height dimensions (Figure 6), and typical connection details (Meyer, 1901, p. 77). After publication of the article by Wohlers (2022), the author relied upon information from the 1901 edition of Engineering Record to replicate a basic set of engineering drawings. The author wishes to show these drawings, which enhance appreciation for the viaduct and may help other engineers explore potential structural concerns. The author welcomes feedback and assistance from other engineers who may wish to contribute to a structural analysis of the Gokteik Viaduct.

\section{REFERENCES}

Meyer HC (ed.) (1901) The Gokteik Viaduct, Burmah-II. In The

Engineering Record, Building Record and Sanitary Engineer, 26 January, XLII(4), pp. 75-78.

Wohlers DC (2022) Potential structural deficiencies within the Gokteik Viaduct Railway Bridge in Upper Burma. Proceedings of the Institution of Civil Engineers - Engineering History and Heritage, https://doi.org/10.1680/jenhh.21.00102.

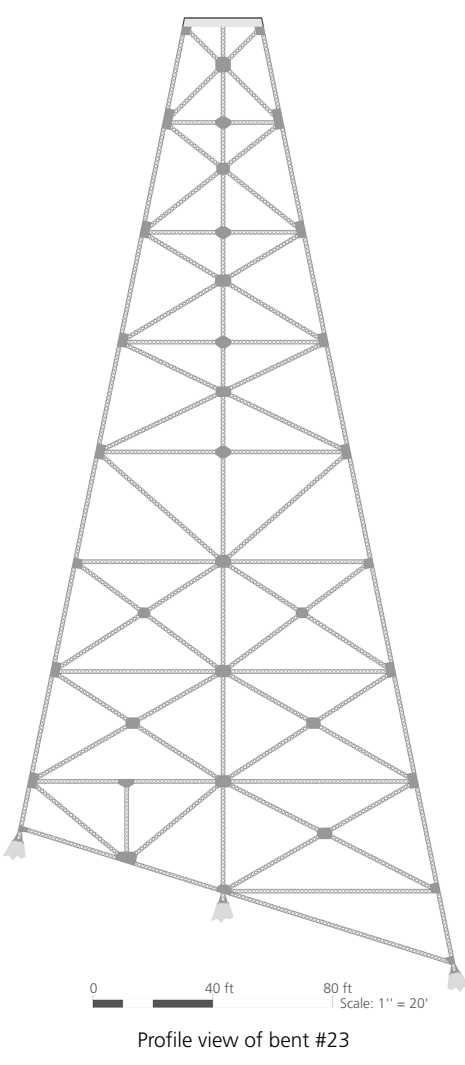

Figure 6. Cross-section of bent \#23

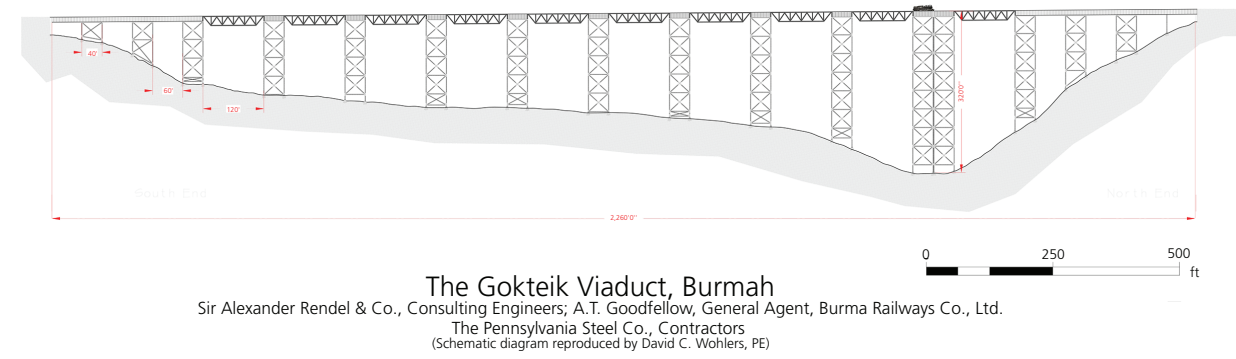

Figure 5. Profile view of the Gokteik Viaduct with a Baldwin Mogul Locomotive (to scale) above bent \#23. Note that the bridge span is $2260 \mathrm{ft}(688.85 \mathrm{~m})$ and a maximum height of $320 \mathrm{ft}(97.54 \mathrm{~m})$ 